\title{
Antibody response to inactivated influenza vaccine given by different routes in patients with chronic bronchopulmonary disease
}

\author{
S. L. SHORE, C. W. POTTER, and C. H. STUART-HARRIS \\ Virus Research Laboratory, Lodge Moor Hospital, and the Departments of Medical Microbiology \\ and Medicine, University of Sheffield
}

\begin{abstract}
Shore, S. L., Potter, C. W., and Stuart-Harris, C. H. (1973). Thorax, 28, 721-728. Antibody response to inactivated influenza vaccine given by different routes in patients with chronic bronchopulmonary disease. A comparison was made of the effects of administering inactivated bivalent influenza vaccine to 30 patients with chronic chest disease by various routes. The vaccine was given by subcutaneous injection to one group, by intranasal and intraoral spray on two successive days to a second group, and by both subcutaneous and intranasal routes to a third group of patients. Most of the patients suffered from chronic bronchitis with airways obstruction but three had asthma. The composition of the groups was adjusted in order that approximately the same number was present in each group of those with or without antibodies to influenza virus A2/Hong Kong/68. The titre of antibodies to this virus was measured in the serum and in sputum before and after immunization.

The results were clearcut in that a greater proportion of those receiving subcutaneous vaccine with or without intranasal vaccine achieved a rise in HI antibodies and a higher titre of serum antibodies than those receiving vaccine purely by the respiratory route. Sputum antibodies were measured by both $\mathrm{HI}$ and tissue culture neutralization tests. The best sputum antibody responses were achieved by those receiving a single dose of subcutaneous vaccine. Those receiving vaccine by the respiratory route only achieved the poorest result and the third group immunized by both routes produced intermediate titres of sputum antibodies, thus suggesting an impairment of the local antibody response. These results are discussed with reference to the method of immunization against influenza of patients with chronic bronchitis.
\end{abstract}

Because of their disturbed ventilatory function, patients with chronic chest disease, such as chronic bronchitis and asthma, suffer severely from the effects of influenza and other acute respiratory infections. The use of prophylactic measures either to prevent or to ameliorate such infections is therefore indicated in the management of these patients. One such measure is influenza vaccination, which, in Britain and the United States, is currently recommended for all patients with chronic bronchopulmonary disorders and other groups at special risk.

Despite the use of influenza vaccines for a number of years, however, many questions still remain. These include the degree of clinical protection and efficacy, the most suitable form of

Requests for reprints: Sir Charles Stuart-Harris, Faculty of Medicine, University of Sheffield, 8 Claremont Place, Sheffield S10 2TN vaccine and whether vaccines should contain inactivated or live attenuated virus, the optimal dosage, and the optimal route of administration (Stuart-Harris, 1970). Little is known about the immune response of patients with chronic lung disease to such vaccines, and particularly that in the secretions of the lower respiratory tract. The presence of antibody in respiratory secretions appears to contribute to host defence against respiratory viruses, although the magnitude of this contribution is still undecided (Rossen, Kasel, and Couch, 1971). One previous study (Waldman, Wood, Torres, and Small, 1970) of patients with chronic pulmonary disease showed a good antibody response in sputa and nasal washings after inactivated vaccine given by aerosol but no response in these secretions after subcutaneously administered vaccine. The serum antibody res- 
T A B L E I

CLINICAL COMPARISON OF VACCINE GROUPS

\begin{tabular}{|c|c|c|c|c|c|c|c|c|}
\hline \multirow{2}{*}{ Group } & \multirow{2}{*}{ Vaccine } & \multirow{2}{*}{ Age } & \multirow{2}{*}{$\begin{array}{c}\text { Sex } \\
(\mathbf{M}, F)\end{array}$} & \multirow{2}{*}{$\mathrm{VC}^{2}$} & \multirow{2}{*}{ FEV $^{3}$} & \multirow{2}{*}{$\begin{array}{l}\text { Diagnosis } \\
(\mathrm{B} / \mathrm{M} / \mathrm{A})^{4}\end{array}$} & \multicolumn{2}{|c|}{ Serum HI Antibody 5} \\
\hline & & & & & & & Titre Range & Seronegative \\
\hline $\mathbf{A}$ & Subcutaneous & $\begin{array}{l}60 \cdot 0 \\
( \pm 9 \cdot 1)^{1}\end{array}$ & 7,4 & $\begin{array}{l}2 \cdot 25 \\
( \pm 0 \cdot 68)\end{array}$ & $\begin{array}{l}40 \\
( \pm 14)\end{array}$ & $6 / 3 / 2$ & $<6-144$ & $7 / 11$ \\
\hline B & Aerosol & $\begin{array}{l}60 \cdot 4 \\
(+7 \cdot 9)\end{array}$ & $9, \quad 1$ & $\begin{array}{l}2 \cdot 22 \\
(+0 \cdot 64)\end{array}$ & 40 & $7 / 2 / 1$ & $<6-96$ & $6 / 10$ \\
\hline C & Combined & $\begin{array}{l}58 \cdot 4 \\
( \pm 7 \cdot 5)\end{array}$ & 7,2 & $\begin{array}{l}2.09 \\
( \pm 0.64)\end{array}$ & $( \pm 12)$ & $6 / 3 / 0$ & $<6-96$ & $5 / 9$ \\
\hline
\end{tabular}

$1 \pm 1 \mathrm{SD}$

${ }^{2}$ Mean vital capacity in litres

${ }^{3}$ Mean forced expiratory volume in $0.75 \mathrm{sec}$. as per cent of vital capacity

B, pure bronchitis; M, mixed bronchitis and reversible airways obstruction; A, asthma

Antibody to A2/Hong Kong/68 before immunization

HI titre $\leqslant 6$

ponse after aerosolized vaccine depended on the size of the droplets, and with those of $1.5 \mu$ was as good as with subcutaneous vaccine. This study, however, was performed with vaccines containing the older A2 Asian strains of influenza virus and in persons with moderately high titres of preexisting antibody.

The results are described below of a trial of inactivated A2/Hong Kong vaccine given either by subcutaneous inoculation or by the respiratory route in 30 patients with chronic bronchopulmonary disease, mostly chronic bronchitis. The antibody response in serum and respiratory secretions was compared after administration of vaccine by the different routes, with particular reference to sputum antibody.

\section{SELECTION OF PATIENTS}

The 30 volunteers were outpatients of a clinic for chronic bronchitis at the Hallamshire Hospital, Sheffield. The patients were chosen on the basis of the pre-existing serum antibody titres to A2/Hong Kong virus and their willingness to participate after full explanation of the nature of the study. Approximately the same proportions of seropositive and seronegative patients were arranged in each of the three vaccine groups described below. Twenty-seven of the 30 patients were diagnosed as having chronic bronchitis with airway obstruction; the other three patients were thought to have chronic bronchial asthma. All patients with chronic bronchitis conformed to the criteria of the Medical Research Council (1965) in that they had produced sputum daily for at least three months of the year and for at least two successive years. The duration of clinical disease was at least five years and exceeded 15-20 years in the majority of patients. The patients ranged in age from 43 to 78 (mean 59.7) years and included both sexes. Ventilatory function studies revealed a diminution in vital capacity and a reduction in the $\mathrm{FEV}_{0.75}$ indicative of a moderate to severs degree of airway obstruction (Table I). The latter? fluctuated widely in the asthmatic patients and to some extent in eight patients with a degree of reversible airway obstruction as well as bron- $\frac{}{3}$ chitis. Some patients were receiving medicationo including antibiotics for exacerbations, broncho $\stackrel{\mathbb{D}}{-}$ dilator drugs, or low doses of corticosteroidso (10 mg of prednisolone daily or less). None of thet patients was receiving iodine expectorants. All denied sensitivity to eggs.

\section{METHODS}

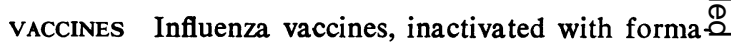
lin and $\beta$ propiolactone and containing 400 inter $\vec{B}$ national Units (IU) per $\mathrm{ml}$ of either A2/Hong Kong/3 68 or $\mathrm{B} /$ England/66 strains, were kindly suppliedb by Dr. D. C. Breeze, Evans Medical Limited, Speke $\frac{7}{0}$ $400 \mathrm{IU}$ is equivalent to approximately $16,000$. haemagglutinating units (HAU).

VACCINE GROUPS The patients were divided intox three groups. Group A (subcutaneous group), con-윽 sisting of 11 patients, received $400 \mathrm{IU}$ of A2/Hong Kong/68 and $200 \mathrm{IU}$ of B/England/66 vaccine subcutaneously. Group B (aerosol group), consisting of 10 patients, received the same amount of vaccine byo aerosol on two consecutive days for a total dosage of $800 \mathrm{IU}$ of $\mathrm{A} 2 / \mathrm{Hong} \mathrm{Kong} / 68$ and $400 \mathrm{IU}$ of B/England/66. Group C (combined group), the remaining 9 patients, received 200 IU of A2/Hong Kong/68 and 100 IU of B/England/66 by sub=cutaneous injection as well as $400 \mathrm{IU}$ of $\mathrm{A} 2 / \mathrm{Hong}$ Kong and $200 \mathrm{IU}$ of $\mathrm{B} /$ England virus by spray on the same day. The aerosol was produced by meanso of a DeVilbiss No. 268 atomizer ${ }^{1}$, which delivers an a verage particle size of 40 microns (Waldman et al., 1970). Of the total vaccine volume of $1.5 \mathrm{ml}, 0.75 \mathrm{~m}$ was given into the oropharynx during inspiration and the remainder was then given equally into both nares. Although the patients tolerated this procedure well, much of the administered vaccine could be seen to? reflect off the pharynx or to condense as droplets in 1Kindly supplied by the DeVilbiss Company, Somerset, Pa., US. 
the pharynx and nose. The vaccines caused only mild local reactions in several patients in groups $\mathbf{A}$ and $\mathbf{C}$ and no reactions in the aerosol group (B). The vaccines were given in February 1971, a time during which no clinical influenza of Hong Kong type was expected in the community and in fact none subsequently occurred. Some disease with the B strain was expected, and for this reason it was decided to give $\mathbf{B}$ as well as Hong Kong vaccine. Since our interest is primarily in the Hong Kong virus, we shall confine our reported results in this paper to the response to the A2/Hong Kong/68 component.

SPECIMENS Serum was obtained at the time of immunization and at 14 and 28 days post-vaccination.

Sputum was collected seven days before vaccination, on the day of vaccination, and on days 7,14 , and 28 post-vaccination. Early morning specimens were brought to the clinic in clean sputum cups, usually within two to three hours of expectoration. A few specimens were kept at home in a refrigerator or cold pantry for six to eight hours. This posed no problem since sputum specimens kept in our laboratory at temperatures up to $37^{\circ} \mathrm{C}$ for similar periods of time showed no diminution in immunoglobulin concentration or antibody titre. All specimens were visibly inspected to rule out the presence of gross blood or unusual salivary contamination and were then frozen at $-20^{\circ} \mathrm{C}$. Only about $5-10 \%$ of specimens were grossly purulent; most were very tenacious and grey-white in colour. Processing of the thawed sputa was by a modification of the method of Waldman et al. (1970) in order to facilitate comparison of data. The specimens were thawed, and penicillin $(100 \mathrm{units} / \mathrm{ml})$ and streptomycin $(100 \mu \mathrm{g} / \mathrm{ml})$ were added. After dialysis for 24 hours against 20 volumes of distilled water containing antibiotics at $4^{\circ} \mathrm{C}$, the sputa were homogenized by being shaken vigorously for 30 seconds with glass beads. A sufficient amount of phosphate-buffered saline, pH 7.4 (PBS), was added before the shaking to ensure separation of the gel and sol phases after centrifugation at $2,500 \mathrm{rpm}$ for 30 minutes. About half of the sputa required only an equal volume of PBS for proper separation, whereas the remaining specimens required two or three (rarely four) volumes of PBS. In general, sputa taken from the same patient on different occasions required the same amount of PBS diluent. The final dilution required did not have any appreciable effect on final protein concentration. The supernatant (sol phase) was then tested for total protein, individual proteins, and antibody by the methods described below.

Nasal washings were collected by instilling a total of $10 \mathrm{ml}$ of sterile PBS into the nares in 1.5 to $2.0 \mathrm{ml}$ aliquots followed by forceful expulsion into a Petri dish. The expelled material was processed as previously described (Downie and Stuart-Harris, 1970). Concentration, where performed, was carried out by dialysis against Carbowax followed by dialysis against PBS.

SEROLOGICAL METHODS Haemagglutination inhibition
(HI) tests were performed in Perspex plates (WHO Expert Committee on Influenza, 1953). Before testing, the specimens were treated with cholera filtrate (Burroughs Wellcome Limited) as described previously (Potter et al., 1972). Eight HAU were used to test sera and 4 HAU to test sputa and nasal washes.

Titrations for neutralizing antibody were carried out by the quantitative haemadsorption technique (Finter, 1967) as described previously (Potter et al., 1972). All specimens were heated to $56^{\circ} \mathrm{C}$ for 30 minutes before testing and were incubated with 100 tissue culture doses of influenza virus A2/Hong Kong/68 prior to inoculation of primary monkey kidney cells.

Sera were tested for complement-fixing antibodies to influenza A group-specific antigen (Downie and Stuart-Harris, 1970). The antigen was extracted from chick embryos infected with A2/Hong Kong/68 virus.

PROTEIN DETERMINATION Processed sputa and nasal washes were assayed for protein by the method of Lowry, Rosebrough, Farr, and Randall (1951).

QUANTITATIVE IMMUNOASSAY Goat antisera to human IgG, IgM, and IgA, and rabbit antisera to human serum albumin (HSA) and lactoferrin were prepared and their specificity confirmed both in reverse radial immunodiffusion as previously described (Reimer, Phillips, Maddison, and Shore, 1970; Phillips et al., 1971; Shore, Phillips, and Reimer, 1971) and in Ouchterlony analysis (OA) and immunoelectrophoresis (IEP) against pooled sputum, nasal washes, and serum. The anti-IgA, made against an $11 S$ secretory IgA from human milk, did not react with secretory piece at the dilution used in the $\operatorname{IgA}$ quantitation test.

The following antigen standards were employed for immunoquantitation: commercially prepared IgG and HSA (Schwarz/Mann, Orangeburg, NY, USA), an $11 S$ secretory IgA (Reimer et al., 1970) for quantitation of IgA in secretions, and lactoferrin from human milk (Johansson, 1969). All antigens were evaluated for purity in OA and IEP. The extinction coefficients employed were 13.8 for both IgG (Schultze and Heremans, 1966) and secretory IgA (Tomasi and Bienenstock, 1968) and 11.7 for lactoferrin (Montreuil, Tonnelat, and Mullet, 1960). For measurement of IgA in serum as well as IgM, a pooled normal human serum was used and concentrations of $2.00 \mathrm{mg} / \mathrm{ml}$ for $\operatorname{IgA}$ and $1.00 \mathrm{mg} / \mathrm{ml}$ for $\operatorname{IgM}$ were assumed.

The level of selected proteins in serum, sputum, and nasal wash was determined by radial immunodiffusion (Mancini, Carbonara, and Heremans, 1965). HSA, IgG, IgA, and IgM were measured in a single pre-immune serum; HSA, IgG, IgA, and lactoferrin were determined for each sputum or nasal specimen. The correlation coefficient for these tests averaged $4 \%$ except for those instances of extremely low antigen concentrations occasionally seen in the nasal washes. Three antigen standards were included on each plate. These determinations of proteins in serum and respiratory secretions were carried out for several reasons: (1) to rule out the presence of hypogammaglobulin- 
aemia or selective $\operatorname{IgA}$ deficiency in any of the patients; (2) to judge the comparability of the three vaccine groups with respect to serum, sputum, and nasal protein concentrations; and (3) to ensure that changes in sputum or nasal antibody levels after vaccination were not spuriously due to extreme variation in immunoglobulin content of specimens collected at different dates from the same patient or to inconsistent yields due to the method of processing.

TESTS FOR STATISTICAL SIGNIFICANCE The statistical significance of the differences found in the number of patients responding with antibody rises in the three vacoine groups was evaluated by Fisher's Exact Test. Differences in mean antibody titres or protein concentrations were evaluated by Student's $t$ test.

\section{RESULTS}

COMPARISON OF VACCINE GROUPS The general similarity of the three vaccine groups is shown by the data in Tables I and II. Although patients were chosen for each group primarily on the basis of pre-existing antibody titre to A2/Hong Kong virus, the groups are similar as regards age, sex, ventilatory function studies, and clinical diagnosis. The serum and sputum protein levels are also similar in the main, but a few group differences are noted. Group A has a significantly lower mean serum IgG and serum IgA concentration than group $C(P<0.05)$. In addition, the serum IgM in group $A$ is lower $(P<0.05)$ than in group $B$. The sputum IgA in group $A$ is almost significantly lower $(P=0.05)$ than in group $B$.

SERUM ANTIBODY RESPONSE Table III shows the serum $H I$ antibody response to vaccination in the three vaccine groups. A greater number of volunteers in groups $\mathrm{A}$ and $\mathrm{C}$ showed a four-fold rise in $\mathrm{HI}$ antibody than was found in group $\mathrm{B}(\mathrm{P}<0.05)$. In addition, the magnitude of rises in groups $A$ and $\mathrm{C}$ was much larger than in group $\mathrm{B}$ : the median titre increase in patients showing significant or probable rises was 48-fold in group A, 28-fold in group $\mathrm{C}$, but only six-fold in group $\mathrm{B}$. The differences in geometric mean titre (GMT) after vaccination between groups $A$ and $B(P<0.001)$ and groups $B$ and $C(P<0.01)$ were statistically highly significant. The serum antibody response to vaccination was generally maximal by two weeks in the two groups receiving subcutaneous vaccine, whereas responders in the aerosol group showed a slight increase in serum antibody titre between two and four weeks. None of the patients in the study showed a rise in complement-fixing antibodies to influenza $A$ antigen.

The two patients in groups $\mathrm{A}$ and $\mathrm{C}$ who failed to show any rise in titre after vaccination were both seropositive; one had an initial HI titre of 144, the

T A B LE I I

SERUM AND SPUTUM PROTEINS

\begin{tabular}{|c|c|c|c|c|c|c|c|c|c|}
\hline \multirow[t]{2}{*}{ Group } & \multicolumn{4}{|c|}{ Serum Proteins ${ }^{1}$} & \multicolumn{5}{|c|}{ Sputum Proteins ${ }^{2}$} \\
\hline & Albumin & IgG & IgA & IgM & $\mathbf{T P}^{3}$ & Albumin & IgG & IgA & $\mathbf{L f}^{4}$ \\
\hline $\begin{array}{l}\mathbf{A} \\
\mathbf{B} \\
\mathbf{C}\end{array}$ & $\begin{array}{l}44 \cdot 0 \\
( \pm 5 \cdot 1)^{5} \\
44 \cdot 0 \\
( \pm 4 \cdot 8) \\
46 \cdot 6 \\
( \pm 2 \cdot 1)\end{array}$ & $\begin{array}{l}11 \cdot 1 \\
( \pm 3 \cdot 1) \\
13 \cdot 1 \\
( \pm 2 \cdot 7) \\
14 \cdot 6 \cdot 6 \\
( \pm 3 \cdot 9)\end{array}$ & $\begin{array}{l}2 \cdot 02 \\
( \pm 0 \cdot 78) \\
2 \cdot 76 \\
( \pm 1 \cdot 17) \\
3 \cdot 04 \\
( \pm 1 \cdot 04)\end{array}$ & $\begin{array}{l}0.66 \\
( \pm 0.37) \\
1.07 \\
( \pm 0 \cdot 31) \\
0.95 \\
( \pm 0.78)\end{array}$ & $\begin{array}{l}2 \cdot 40 \\
( \pm 0.87) \\
2.90 \\
( \pm 0.63) \\
2 \cdot 45 \\
( \pm 1.53)\end{array}$ & $\begin{array}{l}158 \\
( \pm 96) \\
147 \\
( \pm 47) \\
168 \\
( \pm 172)\end{array}$ & $\begin{array}{l}50 \\
( \pm 32) \\
60 \\
( \pm 23) \\
91 \\
( \pm 143)\end{array}$ & $\begin{array}{l}451 \\
( \pm 112) \\
594 \\
( \pm 176) \\
574 \\
( \pm 284)\end{array}$ & $\begin{array}{l}115 \\
( \pm 42) \\
149 \\
( \pm 86) \\
113 \\
( \pm 48)\end{array}$ \\
\hline
\end{tabular}

${ }^{1}$ Serum protein concentrations $(\mathrm{mg} / \mathrm{ml})$

${ }^{5}$ Sputum protein concentrations $(\mu \mathrm{g} / \mathrm{ml})$ except for the total protein $(\mathrm{mg} / \mathrm{ml})$

2Total protein

'Lactoferrin

\pm 1 SD

T A B LE I I I

SERUM HI ANTIBODY RESPONSE TO A2/HONG KONG

\begin{tabular}{|c|c|c|c|c|c|}
\hline \multirow[t]{2}{*}{ Group } & \multirow{2}{*}{$\underset{\text { Rise }^{\mathbf{l}}}{\text { Significant }}$} & \multirow{2}{*}{$\begin{array}{c}\text { Probable } \\
\text { Rise }^{\mathbf{2}}\end{array}$} & \multicolumn{2}{|c|}{ Reciprocal GMT ${ }^{3}$} & \multirow{2}{*}{$\begin{array}{l}\text { Fold } \\
\text { Rise }\end{array}$} \\
\hline & & & Day 0 & Day 28 & \\
\hline & & $1 / 11$ & $\begin{array}{r}9 \cdot 2 \\
(0.9649+0\end{array}$ & 288 & $31 \cdot 3$ \\
\hline $\mathbf{B}$ & $3 / 10$ & $1 / 10$ & $9 \cdot 3$ & 17.7 & 1.9 \\
\hline $\mathbf{C}$ & $8 / 9$ & $0 / 9$ & $\begin{array}{c}(0.96 / 4 \pm 0.0151) \\
12.3 \\
(1.0903 \pm 0.4879)\end{array}$ & $\begin{array}{c}(1 \cdot 2471 \pm 0.58 / 6) \\
281 \\
(2 \cdot 4480 \pm 0.8925)\end{array}$ & $22 \cdot 8$ \\
\hline
\end{tabular}


other a titre of 24. Maximal titres $(>384)$ were more common in seropositive patients in groups $A$ and $C$. In group $B$, all of the three patients showing a significant rise in serum $\mathrm{HI}$ antibody were initially seronegative.

SPUTUM ANTIBODY RESPONSE Table IV shows the sputum HI antibody response to vaccination in the three groups. Antibody rises were noted in 5 of 11 in group A, 2 of 9 in group C, but only 1 of 9 in group B. The GMT rose from 3.26 to 8.95 in group $A, 3.00$ to 4.83 in group $C$, and 3.39 to 4.08 in group $B$. The difference between the final GMTs of groups A and B was just short of statistical significance $(P<0.07)$. The change in titre between 0 and 28 days was highly significant for group $\mathbf{A}$ $(P<0.01)$, of borderline significance in group $C$ $(P<0.08)$, but insignificant for group $B$. In responding patients, the sputum $\mathrm{HI}$ antibody was first detected for some subjects on day 7 after vaccination and reached maximal levels at 14 to 28 days.

Because the HI test, as commonly performed, requires a generous dilution of the specimens under test and is therefore relatively insensitive in detecting low levels of antibody, neutralizing antibody tests were carried out on sputum specimens collected on the day of immunization and 28 days later. These results are shown in Table V. For the patients in group $A, 8$ of 11 showed a rise in neutralizing antibody compared to 4 of 9 in group $C$, and only 1 of 9 in group $B$. The difference in the number of responders in groups $A$ and $B$ was highly significant $(P<0.01)$. The median rise was 11-fold in group $A$ responders and five-fold for group $\mathrm{C}$ responders. Only a single four-fold rise was noted in group B. The rise in GMT was from 1.87 on day 0 to 10.15 on day 28 for group $A, 1.54$ to 3.07 in group C, and 1.17 to 1.63 for group B. The change in GMT between 0 and 28 days was significant in group $\mathbf{A}(\mathbf{P}<0.01)$ but not in groups $B$ and $C(P=0.32$ and 0.18 , respectively). The difference in final GMT between groups A and B was highly significant $(P<0.01)$, and there was also a borderline significant difference $(P=0.05)$ between the final GMT in groups $A$ and $C$.

Excellent correlation was noted between the HI and neutralizing antibody tests: all patients who showed rises by the $\mathrm{HI}$ test also showed a rise in the neutralization test, and those whose sputa showed no rise by the HI test showed either no rise at all or only a modest rise in neutralizing antibody. Sputum antibody changes in a given patient after vaccination were not secondary to variation in the content of $\operatorname{IgA}$ or IgG in the sputa, since quantitation by radial immunodiffusion showed relatively small variation in specimens taken from the same patient on different dates. Accordingly, the sputum titres previously noted are given in absolute numbers and not in terms of a standard concentration unit of IgG or IgA. None of the patients in the study showed a serious deficiency in the levels of the immunoglobulins normally found in serum or sputum; it is therefore unlikely that failure to produce antibody after vaccination was due to the presence of one of the wellrecognized antibody deficiency syndromes.

T A B L E I V

SPUTUM HI ANTIBODY RESPONSE TO A2/HONG KONG

\begin{tabular}{|c|c|c|c|c|c|}
\hline \multirow{2}{*}{ Group } & \multirow{2}{*}{$\underset{\text { Rise }}{\text { Significant }}$} & \multirow{2}{*}{$\begin{array}{l}\text { Probable } \\
\text { Rise }\end{array}$} & \multicolumn{2}{|c|}{ Reciprocal GMT } & \multirow{2}{*}{$\begin{array}{l}\text { Fold } \\
\text { Rise }\end{array}$} \\
\hline & & & Day 0 & Day 28 & \\
\hline $\mathbf{A}$ & $4 / 11$ & $1 / 11$ & $\begin{array}{c}3.26 \\
(0.5133+0.1200)\end{array}$ & $\begin{array}{c}8.95 \\
(0.9516+0.5073)\end{array}$ & $2 \cdot 7$ \\
\hline B & $1 / 9^{1}$ & $1 / 9$ & $\begin{array}{c}3.39 \\
(0.5301+0.1590)\end{array}$ & 4.08 & $1 \cdot 2$ \\
\hline C & $2 / 9$ & $1 / 9$ & $(0.4771 \pm 0.0000)$ & $\begin{array}{c}4.83 \\
(0.6835 \pm 0.3187)\end{array}$ & $1 \cdot 6$ \\
\hline
\end{tabular}

${ }^{1}$ One patient in group B did not produce any sputum after vaccination. Therefore, sputum data are available for only 9 of 10 patients in this group.

TABLE V

SPUTUM NEUTRALIZING ANTIBODY RESPONSE TO A2/HONG KONG

\begin{tabular}{|c|c|c|c|c|c|}
\hline \multirow[t]{2}{*}{ Group } & \multirow{2}{*}{$\begin{array}{c}\text { Significant } \\
\text { Rise }\end{array}$} & \multirow{2}{*}{$\begin{array}{c}\text { Probable } \\
\text { Rise }\end{array}$} & \multicolumn{2}{|c|}{ Reciprocal GMT' } & \multirow{2}{*}{$\begin{array}{l}\text { Fold } \\
\text { Rise }\end{array}$} \\
\hline & & & Day $O$ & Day 28 & \\
\hline $\mathbf{A}$ & $8 / 11$ & $0 / 11$ & 1.87 & $10 \cdot 15$ & $5 \cdot 4$ \\
\hline $\mathbf{B}$ & $1 / 9$ & $2 / 9$ & $\begin{array}{c}(0.211 \pm 0.3901) \\
1 \cdot 17\end{array}$ & 1.63 & $1 \cdot 4$ \\
\hline C & $4 / 9$ & $0 / 9$ & $\begin{array}{c}(0.0669 \pm 0.2001) \\
1 \cdot 54 \\
(0 \cdot 1888 \pm 0.3821)\end{array}$ & $\begin{array}{c}(0.2144 \pm 0.3634) \\
3.07 \\
(0.4868 \pm 0.5137)\end{array}$ & $2 \cdot 0$ \\
\hline
\end{tabular}

${ }^{1}$ For purposes of computation, negative titres $(<2)$ are assigned a value of 1 . 
Rises in sputum antibody in all three vaccine groups were accompanied by rises in serum antibody titre. From a quantitative standpoint, however, although there was a tendency for the highest sputum antibody responses to parallel the strongest serum antibody responses, the correlation between the two was not invariable. For example, a few patients with very large rises in serum antibody after vaccination showed only modest increases in sputum antibody compared to other patients with equivalent serum antibody rises and serum antibody titres. This observed variation from patient to patient could not be explained simply by a consideration of the serum/sputum IgG ratios in the different subjects. In particular, when compared at equivalent serum antibody titres, patients in group A had higher sputum antibody titres than patients in group $C$. This phenomenon is reflected in Tables III, IV, and V, where a higher sputum HI and neutralizing GMT at 28 days was found in group $\mathrm{A}$ as compared to group C despite similar serum HI antibody GMTs. Of the three patients in the aerosol group (B) who showed a four-fold or greater serum antibody rise, only one had a significant rise in sputum antibody.

The presence or absence of sputum antibody before vaccination did not have any noticeable influence on the subsequent response to vaccine.

NASAL ANTIBODY RESPONSE. The results obtained for the nasal antibody response are more difficult to interpret than the sputum antibody data because of technical problems. Owing to their difficulty in breathing, the majority of patients tolerated the nasal wash procedure rather poorly and were able to expel only small or irregular amounts of wash effluate. As a result, striking variations in the content of $\operatorname{IgA}$ and IgG, occasionally as high as fiveto 10-fold, were found in specimens taken from the same patient at different times in the study. Even after four- to five-fold concentrations of the nasal specimens, the average concentration of the two immunoglobulins was lower than in the sputum specimens, approximately four-fold lower for IgG and nine-fold lower for IgA. In addition, the volume of the specimens obtained from some patients precluded doing the full battery of tests; on occasion, pooling of several post-vaccination specimens from the same patient was necessary to provide an adequate specimen volume for testing.

With these reservations, the nasal antibody data, uncorrected for $\operatorname{IgA}$ or IgG concentration, are as follows. HI antibody, either in concentrated or unconcentrated nasal wash specimens, could not be detected in any patient in any of the three vaccine groups. Neutralization tests on concen- trated specimens, however, showed a four-fold or greater rise in 4 or 8 patients in group $\mathrm{A}$, in 0 of 10 patients in group $B$, and in 2 of 8 patients in group $C$. The difference between groups $A$ and $B$ is statistically significant $(P<0.05)$.

\section{DISCUSSION}

The patients with chronic bronchopulmonary disease in this study showed a significantly better antibody response to vaccine administered parenterally rather than by the respiratory route. This was true for sputum and nasal antibody as well as for serum antibody. In addition to the striking rise in serum antibody noted, 8 of 11 patients receiving the full dose of parenteral vaccine showed a significant rise in sputum neutralizing antibody. Patients who received only the aerosol vaccine showed a much poorer serum antibody response and, in addition, a poorer sputum neutralizing antibody response. No additive or synergistic effect on antibody levels in respiratory secretions was noted when giving parenteral and aerosol vaccines on the same day; however, the combined route of vaccination may have had some additive effect on the serum antibody response since group $C$ patients, who received only half the parenteral dose of vaccine given to group $A$, had the same final geometric mean titre as group $\mathrm{A}$. That the parenteral dosage employed may be critical in producing antibody in respiratory secretions is shown by the more frequent and higher sputum antibody response in group $\mathrm{A}$ as compared to group $\mathrm{C}$. This finding is in accord with the data of Mostow et al. (1970), who found an increase in the frequency of nasal antibody after increasing the parenteral dosage of inactivated A2/Hong Kong/ 68 vaccine in normal volunteers. Our serum antibody findings are also in agreement with those of Gwaltney, Edmondson, Rothenberg, and White (1971), who found a decisively better response to parenteral than to aerosol vaccine in normal subjects. Unfortunately, measurements of sputum or nasal antibodies were not reported in their study.

Our findings are somewhat at variance with those of Waldman et al. (1970), who found a fourfold or greater rise in the sputum neutralizing antibody titre after aerosol immunization in each of seven patients with chronic lung disease in the United States. This group of investigators also reported a failure of parenteral vaccine, in a similar dosage to ours, to stimulate a sputum neutralizing antibody response; however, in their paper it is not clear whether the subjects given parenteral vaccine were patients with severe chronic lung disease or simply 'normal' volunteers 
who could produce small amounts of thin scanty sputum because of smoking. To some extent the different results in the two studies may be due to the fact that the earlier study employed a different virus vaccine strain (an earlier Asian A2 strain) and immunized a group of patients with a higher serum antibody titre against the homologous virus. In our present study, over half of our patients were seronegative to the A2/Hong Kong/68 virus employed in the vaccine. It has been reported that healthy seropositive persons have a better nasal antibody response to local respiratory vaccine than do seronegative individuals; the latter tend to respond with the production of serum antibody but not nasal antibody (Rossen et al. 1971). Three of our seronegative patients in group B (aerosol group) showed this phenomenon of serum antibody response unaccompanied by detectable respiratory antibody formation. None of the seropositive patients behaved in this way.

The nature of the antibody found in the sputum of the parenterally immunized patients is of interest. It seems likely that at least a portion of the sputum antibody is derived from the serum in those individuals with high post-vaccination serum antibody titres. This follows from the observations that human serum antibody stimulated by inactivated influenza vaccine is of the IgG class (Waldman, Mann, and Kasel, 1967) and that most of the sputum IgG in chronic bronchitic patients is serum-derived rather than locally produced (Shore et al., in preparation). Although the IgG concentration is approximately 200 -fold lower in sputum than in serum (Table V), high titres of serum IgG antibody ( $>384$, for example) would be expected to produce measurable levels of antibody in sputum by simple diffusion. It is unlikely, however, that all of the sputum antibody is derived from the serum for a number of reasons. First, a comparison of the ratios of antibody to IgG concentration in sputum and serum suggests that an excessive amount of antibody is present in sputum. Secondly, there is an imperfect correlation of sputum and serum antibody titres. This is best demonstrated by a comparison of vaccine groups $A$ and $C$, both of which demonstrated similar postvaccination geometric titres in serum but different antibody titres in sputum. Thus, it is probable that part of the sputum antibody in these patients was produced locally in the respiratory tract. It is not known at present whether this local antibody belongs to either the IgA or IgG class of immunoglobulins, although preliminary studies in our laboratory using density gradient ultracentrifugation imply a contribution of antibody of the secretory IgA type as well as of the IgG type.
Contrary to a previous report (Medici and Buergi, 1971), the patients with chronic bronchitis in the present study produced adequate amounts of secretory IgA in their sputum (Shore et al., in preparation). Locally produced or actively transported IgG was also present in their sputum in small amounts (Shore et al., in preparation) so that not all local antibody is necessarily of the IgA class.

Because of the increased risk of complications from influenzal disease in patients with chronic bronchopulmonary disease, it is important to know that immunization with a standard dose of influenza vaccine given by the standard subcutaneous route can produce good levels of sputum as well as serum antibodies. Whether sputum antibodies have a role in preventing lower respiratory involvement and complications in influenza infection remains to be demonstrated.

\section{REFERENCES}

Downie, J. C. and Stuart-Harris, C. H. (1970). The production of neutralizing activity in serum and nasal secretion following immunization with influenza B virus. Journal of Hygiene, 68, 233.

Finter, N. B. (1967). Quantitative hemadsorption: A new assay technique. II. Assay of neutralizing antibodies to hemadsorbing viruses. Journal of Immunology, 98, 88.

Gwaltney, J. M. Jr., Edmondson, W. P. Jr., Rothenberg, R., and White, P. W. (1971). A comparison of subcutaneous, nasal, and combined influenza vaccination 1. Antigenicity. American Journal of Epidemiology, 93, 472.

Johansson, B. G. (1969). Isolation of crystalline lactoferrin from human milk. Acta chemica Scandinavica, 23, 683.

Lowry. O. H., Rosebrough, N. J., Farr, A. L., and Randall, R. J. (1951). Protein measurement with the Folin phenol reagent. Journal of Biological Chemistry, 193, 265.

Mancini, G., Carbonara, A. O., and Heremans, J. F. (1965). Immunochemical quantitation of antigens by single radial immunodiffusion. Immunochemistry, 2, 235.

Medical Research Council (1965). Report by the Committee on the Aetiology of Chronic Bronchitis. Definition and classification of chronic bronchitis for clinical and epidemiological purposes. Lancet, I, 775.

Medici, T. C. and Buergi, H. (1971). The role of immunoglobulin $\mathbf{A}$ in endogenous bronchial defence mechanisms in chronic bronchitis. American Review of Respiratory Diseases, 103, 784.

Montreuil, J., Tonnelat, J., and Mullet, S. (1960). Préparation et propriétés de la lactosidérophiline (lactotransferrine) du lait de femme. Biochimica Biophysica Acta, 45, 413.

Mostow, S. R., Schoenbaum, S. C., Dowdle, W. R., Coleman, M. T., Kaye, H. S., and Hierholzer, J. C. (1970). Studies on inactivated influenza vaccines II. Effect of increasing dosage on antibody response and adverse reactions in man. American Journal of Epidemiology, 92, 248.

Phillips, D. J., Shore, S. L., Maddison, S. E., Gordon, D. S., and Reimer, C. B. (1971). Comparative evaluation of commercial precipitating antisera against human IgA. Journal of Laboratory and Clinical Medicine, 77, 639. 
Potter, C. W., Oxford, J. S., Shore, S. L., McLaren, C., and Stuart-Harris, C. H. (1972). Immunity to influenza in ferrets. 1. Response to live and killed virus. British Journal of Experimental Pathology, 53, 153.

Reimer, C. B., Phillips, D. J., Maddison, S. E., and Shore, S. L. (1970). Comparative evaluation of commercial precipitating antisera against human IgM and IgG. Journal of Laboratory and Clinical Medicine, 76, 949.

Rossen, R. D., Kasel, J. A., and Couch, R. B. (1971). The secretory immune system: Its relation to respiratory viral infection. In Progress in Medical Virology, 13, p. 194. Ed. J. L. Melnick. Karger, Basel.

Schultze, H. E. and Heremans, J. F. (1966) Molecular Biology of Human Proteins. Elsevier, Amsterdam.

Shore, S. L., Phillips, D. J., and Reimer, C. B. (1971). Umbrella effect: pitfall in analysis of specificity of antisera to immunoglobulins. Immunochemistry 8, 562.
Stuart-Harris, C. H. (1970). Control of influenza: lack of knowledge versus lack of application of knowledge. Archives of Environmental Health, 21, 276.

Tomasi, T. B. and Bienenstock, J. (1968). Secretory immunoglobulins. Advances in Immunology, 9, 1.

Waldman, R. H., Mann, J. J., and Kasel, J. A. (1967). Immunoglobulin classes of serum neutralizing antibody found in response to immunization with dead influenza virus vaccine. Proceedings of the Society of Experimental Biology and Medicine, 126, 838.

—, Wood, S. H., Torres, E. J., and Small, P. A. Jr. (1970). Influenza antibody response following aerosol administration of inactivated virus. American Journal of Epidemiology, 91, 575.

WHO Expert Committee on Influenza (1953). Technica Report Series, No. 64. World Health Organization, Geneva. 